\title{
Pantanal Mato-grossense: um patrimônio nacional à margem da lei
}

\section{Cintya Leocádio Dias Cunha}

Mestranda em Direito Agroambiental pela Universidade Federal de Mato Grosso. Especialista em Direito Processual Civil pela Uniderp - Anhanguera. Professora da Faculdade de Direito da Universidade do Estado de Mato Grosso. Advogada.

\begin{abstract}
Sumário: 1. Introdução; 2. A Constituição Federal de 1988 e a proteção ambiental; 2.1. O meio ambiente ecologicamente equilibrado como direito fundamental; 2.2. O meio ambiente como direito difuso; 3. Pantanal Mato-grossense: um patrimônio nacional desprotegido; 3.1. Algumas mudanças legislativas sobre a proteção ambiental no Brasil; 3.2. A "proteção jurídica" do Pantanal Mato-grossense como patrimônio nacional; 4. Conclusão; 5. Referências.
\end{abstract}

\section{Introdução}

O presente trabalho propõe uma reflexão acerca da necessidade de uma lei específica que proteja o Pantanal Mato-grossense, valendo-se, para tanto, de fontes doutrinárias e jurisprudenciais. Assim, a metodologia pauta-se no levantamento bibliográfico e documental.

A Constituição Federal de 1988, no artigo 225, § $4^{\circ}$, reconheceu o Pantanal Mato-grossense como um patrimônio nacional. O estudo do tema proposto busca justamente verificar e analisar se esta área geográfica, reconhecida pelo Constituinte, está sendo juridicamente protegida.

Para atingir esse objetivo, este trabalho foi realizado em duas partes.

A primeira almeja discorrer sobre o reconhecimento do direito ao meio ambiente - no caso, a manutenção do equilibrio ecológico do Pantanal —, como direito fundamental.

A segunda parte apresentará as características do bioma, analisará documentos internacionais relevantes ao Pantanal, ressaltando-se a carência de legislação específica que efetivamente o proteja.

Por fim, será apresentada uma conclusão sobre o tema debatido, perquirindo-se a necessidade da promulgação de uma lei específica para o Pantanal. 


\section{A Constituição Federal de 1988 e a proteção ambiental}

\subsection{O meio ambiente ecologicamente equilibrado como direito fundamental}

A concepção multifuncional ${ }^{1}$ dos direitos fundamentais, fruto do Estado do bem-estar social, reconhece que os direitos fundamentais servem à proteção e materialização de bens importantes para a comunidade e não apenas à defesa do indivíduo contra o Estado.

A proteção ao meio ambiente está abalizada no artigo 225, caput, incisos e parágrafos, da Constituição Federal de 1988, ao descrever que todos (as presentes e futuras gerações) têm direito ao meio ambiente ecologicamente equilibrado e que este deve ser defendido e preservado pelo poder público e pela coletividade:

Art. 225. Todos têm direito ao meio ambiente ecologicamente equilibrado, bem de uso comum do povo e essencial à sadia qualidade de vida, impondo-se ao Poder Público e à coletividade o dever de defendê-lo e preservá-lo para as presentes e futuras gerações. ${ }^{2}$

A Carta Magna não define o que vem a ser meio ambiente. Tal conceito normativo ficou a cargo da Lei n. 6.938/81, que define a Política Nacional do Meio Ambiente, especificamente no artigo $3^{\circ}$, inciso I:

Art $3^{\circ}$ - Para os fins previstos nesta Lei, entende-se por: I - meio ambiente, o conjunto de condições, leis, influências e interações de ordem física, química e biológica, que permite, abriga e rege a vida em todas as suas formas. ${ }^{3}$

A hermenêutica jurídica reconhece que o equilibrio ecológico do meio ambiente é direito fundamental estampado na Constituição Federal de 1988, logo, com maior razão merece este status constitucional a preservação do Pantanal Mato-grossense, por ser reconhecido constitucionalmente como patrimônio nacional brasileiro.

No plano internacional, o interesse na manutenção do meio ambiente ecologicamente equilibrado está respaldado em vários documentos internacionais,

1 SARLET, Ingo Wolfgang. A eficácia dos direitos fundamentais. 3. ed. rev. atual. ampl. Porto Alegre: Livraria do advogado, 2003. p. 160.

2 BRASIL. Constituição da República de 1988. Planalto. Disponível em: < http://www.planalto.gov.br/ccivil_03/ constituicao/constituicaocompilado.htm > Acesso em: 2. jan. 2016.

3 BRASIL. Lei $\mathrm{n}^{\circ}$ 6.938, de 31 de agosto de 1981. Planalto. Dispõe sobre a política nacional do meio ambiente e dá outras providências. Disponível em: < http://www.planalto.gov.br/ccivil 03/Leis/L6938.htm > Acesso em: 29 dez. 2015. 
como na Declaração da Conferência das Nações Unidas sobre Meio Ambiente, realizada em 1972, em Estocolmo:

Princípio I - O homem tem o direito fundamental à liberdade, à igualdade, e ao desfrute de condições de vida adequada em um meio cuja qualidade lhe permite levar uma vida digna e gozar de bem-estar e tem a solene obrigação de proteger e melhorar esse meio para as gerações presentes e futuras [...] Princípio II - Os recursos naturais da terra incluso o ar, a água, a terra, a flora e a fauna e especialmente as amostras representativas dos ecossistemas naturais devem ser preservados em benefício das gerações presentes e futuras, mediante uma cuidadosa planificação ou regulamentação segundo seja mais conveniente. ${ }^{4}$

Alguns anos mais tarde, precisamente vinte anos depois, a Declaração da Conferência das Nações Unidas sobre Meio Ambiente e Desenvolvimento, realizada no Rio de Janeiro, em 1992, novamente sustentou no plano internacional a importância do direito ao meio ambiente: "Os seres humanos constituem o centro das preocupações relacionadas com o desenvolvimento sustentável. Têm direito a uma vida saudável e produtiva, em harmonia com a natureza". 5

O respaldo constitucional para que o direito ao meio ambiente seja considerado direito fundamental está no artigo $5^{\circ}$, parágrafo $2^{\circ}$, primeira parte, da Constituição Federal, que legitima outros direitos como fundamentais mesmo que não estejam expressos no artigo $5^{\circ}$, da Carta Magna, desde que decorram dos princípios por ela adotados. Cabe ressaltar que o princípio do meio ambiente ecologicamente equilibrado que assegura o direito ao meio ambiente é adotado de forma expressa pela Constituição, apenas não está previsto no art. $5^{\circ}$.

Assim, o fato de a proteção do meio ambiente constar no Título VIII, da Constituição Federal, reservado à Ordem Social e não estar localizado no Título II, da Carta Magna, que trata dos Direitos e Garantias Fundamentais, não desfigura sua classificação como direito fundamental, pois o rol dos direitos fundamentais é formado por aqueles direitos explicitamente descritos no artigo $5^{\circ}$, bem como aqueles implicitamente assim considerados.

Admite-se também a recepção do direito ao meio ambiente equilibrado no rol dos direitos fundamentais, por força da Declaração do Meio Am-

4 ORGANIZAÇÃO DAS NAÇÕES UNIDAS. Declaração da Conferência das Nações Unidas sobre Meio Ambiente. Estocolmo: 5 a 16 de junho de 1972. Disponível em: < http://www.onu.org.br/rio20/img/2012/01/ estocolmo1972 > Acesso em: 10 jan. 2016.

5 ORGANIZAÇÃO DAS NAÇÕES UNIDAS. Declaração da Conferência das Nações Unidas sobre Meio Ambiente e Desenvolvimento. Rio de Janeiro: 3 a 14 de junho de 1992. Disponível em: $<\underline{\text { http://www.onu. }}$ org.br/rio20/img/2012/01/estocolmo1972 > Acesso em: 10 jan. 2016. 
biente, em Estocolmo, já citada, da qual o Brasil participou, com base no artigo $5^{\circ}, \S 2^{\circ}$, segunda parte, da Constituição, que legitima outros direitos como fundamentais mesmo que não estejam expressos na Constituição Federal, desde que decorram de tratados internacionais em que a República Federativa do Brasil seja parte. Aqui a Declaração de Estocolmo deve ser considerada como um documento internacional que serviu e serve como paradigma para a proteção ambiental. Cabe transcrever o artigo 5ำ, parágrafo $2^{\underline{0}}$, da Constituição Federal:

Art. $5^{\circ}$ Todos são iguais perante a lei, sem distinção de qualquer natureza, garantindo-se aos brasileiros e aos estrangeiros residentes no País a inviolabilidade do direito à vida, à liberdade, à igualdade, à segurança e à propriedade, nos termos seguintes: [...] $\S 2^{\circ}$ Os direitos e garantias expressos nesta Constituição não excluem outros decorrentes do regime e dos princípios por ela adotados, ou dos tratados internacionais em que a República Federativa do Brasil seja parte. ${ }^{6}$

A interpretação destes dispositivos, nos moldes acima apresentados, assegura o direito ao meio ambiente no rol dos direitos fundamentais. No caso do Pantanal Mato-grossense, para que a máxima efetividade do direito fundamental ao meio ambiente seja atingida e para que realmente o direito fundamental seja real e efetivo são necessárias políticas públicas engajadas no desenvolvimento sustentável desta região. No campo legislativo é preciso a promulgação de uma lei específica do Pantanal, que assegure a proteção dessa área, garantindo a preservação do meio ambiente, principalmente, no que diz respeito ao uso dos recurso naturais. Assim, afirma Marcelo Sodré:

A própria Constituição Federal fixa que para assegurar a efetividade do direito a um meio ambiente ecologicamente equilibrado incumbe ao Poder Público controlar a produção, comercialização e o emprego de técnicas, métodos e substâncias que comportem risco para a vida, a qualidade de vida e o meio ambiente (art. 225, V).

O Pantanal Mato-grossense, localizado nos estados de Mato Grosso e Mato Grosso do Sul, considerado como patrimônio nacional, não possui uma lei federal que justifique e regulamente este patrimônio, apenas é

6 BRASIL. Constituição da República de 1988. Planalto. Disponível em: < http://www.planalto.gov.br/ ccivil_03/constituicao/constituicaocompilado.htm > Acesso em: 2 jan. 2016.

7 SODRÉ, Marcelo. Dignidade Planetária: O Direito e o Consumo Sustentável. In: MIRANDA, Jorge; SILVA, Marco Antonio Marques da (Coord.). Tratado Luso-Brasileiro da Dignidade Humana. São Paulo: Quartier Latin, 2008,. p. 1171. 
regido por uma lei do estado de Mato Grosso de 2008, que será analisada em outro tópico.

Vigora na Constituição o Princípio da Universalidade, que sustenta que o direito ao meio ambiente ecologicamente equilibrado não é reservado somente aos brasileiros, mas que a defesa ambiental tem legitimação internacional, incluindo os estrangeiros. Neste sentido, Jorge Miranda aduz que "a proteção da dignidade da pessoa, assim como a tutela ao meio ambiente, está para além da cidadania brasileira e postula uma visão universalista da atribuição dos direitos". 8

Marcelo Abelha clama por uma titularidade mais abrangente do direito ao meio ambiente:

A titularidade do direito em questão, pela sua complexidade, demanda uma análise mais profunda do que a simples avaliação do sentido da expressão "todos", pois é na caracterização do bem ambiental - marcado pela fórmula equilibrio ecológico - que será extraído do caput do artigo 225 uma clara opção biocêntrica do legislador constitucional. Assim, pensando, quanto ao meio ambiente ecologicamente equilibrado, são amplas as possibilidades de se defender que "todas as formas de vida são seus titulares".?

Assim, a expressão "todos têm direito ao meio ambiente ecologicamente equilibrado", como previsão constitucional, tem diversas interpretações, mas deve ser utilizada aquela que mais viabilize a proteção do meio ambiente, ponto máximo do direito ambiental.

A Carta Magna de 1988 reconheceu o dever de preservação do meio ambiente para as presentes e futuras gerações, também conhecida como "Teoria da equidade intergeracional”, que tem grande semelhança com o estipulado no documento da Organização das Nações Unidas, publicado em 1988, intitulado "Goa Guidelines on Intergenerational Equity". Trata-se de um documento internacional que prega a importância de se preservar um patrimônio natural para as gerações vindouras.

Documentos internacionais como as Convenções sobre a Proteção do Patrimônio Natural e Cultural; sobre o Comércio Internacional de espécies ameaçadas e sobre a Poluição dos Oceanos, de Londres, retratam a importância da manutenção das condições de vida para as futuras gerações. O próprio

8 MIRANDA, Jorge. Manual de direito constitucional. 2. ed. t. IV. Coimbra: Coimbra ed., 1993. p. 169.

9 RODRIGUES, Marcelo Abelha. Instituições de direito ambiental. v. 1. São Paulo: Max Limond, 2002. p. 61. 
conceito de desenvolvimento sustentável previsto no Relatório de Brundtland/ Nosso Futuro Comum - "aquele que atende às necessidades do presente sem comprometer a possibilidade de as gerações futuras atenderem a suas próprias necessidades"10 — traz a ideia de equilibrio ambiental pautado no uso racional dos recursos naturais para não causar a escassez destes bens ambientais para as futuras gerações.

Em contrapartida, há na doutrina ${ }^{11}$ defensores de pensamentos opostos, não responsabilizando as presentes gerações pela manutenção do meio ambiente para as gerações que ainda nem sequer existem no cenário mundial.

No estado de Mato Grosso, onde está situada parte do Pantanal, há estudos ${ }^{12}$ que comprovam a inexistência de uma relação ética, pautada no respeito com o outro ser que ainda nem sequer foi concebido ou, se concebido, ainda não nasceu, um sujeito com expectativas de direito ou com direitos plenos a depender da corrente adotada sobre o nascituro.

Certo é que agrotóxicos já foram encontrados no leite materno na cidade de Lucas do Rio Verde, provenientes do agronegócio que toma conta do solo mato-grossense. Estudos comprovam a associação deste leite contaminado com os fertilizantes utilizados na lavoura de soja, milho e demais grãos, conforme apontam diversos estudos de autoria do professor Pignati.

Com base nestas pesquisas, nota-se que o agronegócio já afeta o Pantanal, bem como há indícios de projetos que têm como meta expandir as plantações de grãos, o que ocasionará ainda mais poluição deste santuário ecológico. É a verdadeira institucionalização da sociedade de risco teorizada por Ulrich Beck $^{13}$ no Pantanal. Não há como se falar em meio ambiente preservado para as futuras gerações se nem as presentes gerações estão podendo usufruí-lo.

10 BRUNDTLAND, G. H. Nosso Futuro Comum: Comissão mundial sobre meio ambiente e desenvolvimento. 2. ed. Rio de Janeiro: Fundação Getúlio Vargas, 1991. p. 43.

11 José Casalta Nabais não entende ser possível a atribuição de direitos cujos titulares ativos sejam as gerações futuras, o que, como destaca, seria uma forma equivocada de dizer que sobre a atual geração humana recaem deveres de indivíduos, grupos e organizações para com as gerações futuras, orientando-nos no sentido da preservação no futuro na comunidade atual através da prevenção de riscos e perigos que possam vir a inviabilizar ou onerar excessivamente a vida das gerações futuras. Haveria apenas deveres de proteção ambiental da geração humana presente para com ela mesma, não sendo possível o reconhecimento de algum direito atribuível às gerações futuras, de modo, inclusive, a limitar os direitos fundamentais das gerações viventes. Cf. NABAIS, José Casalta. O dever fundamental de pagar impostos: contributo para a compreensão constitucional do estado fiscal contemporâneo. Coimbra: Almedina, 1998. p. 54.

12 PIGNATI, Wanderlei. Avaliação integrada dos impactos dos agrotóxicos na saúde e ambiente em Lucas do Rio Verde no Mato, com ênfase na contaminação do leite materno. Disponível em: < http:// www2.camara.leg.br/atividade-legislativa/comissoes/comissoes-permanentes/cmads/audiencias-publicas/ audiencias-publicas/3-07-2012-presenca-de-residuos-de-agrotoxicos-em-leite-materno/heloisa-rey-farza-anvisa/professor-dr.wanderlei-pignati-ufmt $>$ Acesso em: 23. fev. 2016.

13 Cf. BECK, Ulrich. La sociedad del riesgo: hacia una nueva modernidad. Barcelona, Paidós, 1998. 


\subsection{O meio ambiente como direito difuso}

Cabe salientar que o direito ao meio ambiente é reconhecido constitucionalmente como um direito fundamental difuso, é um bem de uso comum ${ }^{14}$. A respeito dos direitos difusos, Rodolfo Mancuso aduz que:

[...] poderá haver um momento no qual um interesse difuso, à força de ser continuamente revelado e exercitado no seio da comunidade, venha a ganhar foros de uma liberdade pública, a nível constitucional, expressa ou implicitamente. ${ }^{15}$

Diante desta afirmação, torna-se necessário caracterizar estes direitos difusos. Segundo Patricia Faga Iglecias Lemos:

Interesse difuso é o direito transindividual, de natureza indivisível, de que são titulares pessoas indeterminadas, ligadas por circunstâncias de fato, como habitar na mesma região, consumir iguais produtos, expor-se aos efeitos de determinado serviço perigoso ou de uma publicidade enganosa. ${ }^{16}$

Ainda com referência aos direitos difusos, sustenta Mancuso:

São interesses metaindividuais que não tendo atingido o grau de agregação e organização necessário à sua afetação institucional junto a certas entidades ou órgãos representativos dos interesses já socialmente definidos, restam em estado fluido dispersos pela sociedade civil como um todo, podendo por vezes concernir a certa coletividade de conteúdo numérico indefinido. ${ }^{17}$

Por sua vez, Ada Pelegrini Grinover pontua que:

Os interesses difusos são direitos supraindividuais que pertencem a um número indeterminado e praticamente indeterminável de pessoas, as quais não têm entre si nenhuma relação definida e encontram-se em uma mesma situação, muitas vezes acidentalmente. Por isso, diz-se que seu objeto é indivisível, sua proteção beneficia a todos. Por isso, interesse difuso não é a soma de direitos individuais mas um único direito pertencente a todos, que não tem a sua tutela sujeita ao monopólio estatal. ${ }^{18}$

14 ZAVASCKI, Teori, A. Defesa de direitos coletivos e defesa coletiva de direitos. Revista de informação legislativa, Brasilia, Senado Federal, v. 32, n. 127, p. 83-96, jul./set. 1995.

15 MANCUSO, Rodolfo de Camargo. Interesses difusos. São Paulo: RT, 1998. p. 85.

16 LEMOS, Patricia Faga Iglesias. Meio ambiente e responsabilidade civil do proprietário: análise do nexo causal. 1. ed. São Paulo: Editora Revista dos Tribunais, 2008. p. 95.

17 MANCUSO, Rodolfo de Camargo. Interesses difusos. Op. cit., p.105.

18 GRINOVER, Ada Pellegrini (Coord.). A tutela jurisdicional dos interesses difusos. São Paulo: Editora Max Limonad, 1984. p. 70. 
A doutrina ${ }^{19}$ reconhece que no âmbito do processo coletivo interesse e direito são termos sinônimos, sendo esta, inclusive, a orientação do Código de Defesa do Consumidor, normatização pertencente ao microssistema processual coletivo brasileiro:

Art. 81. A defesa dos interesses e direitos dos consumidores e das vítimas poderá ser exercida em juízo individualmente, ou a título coletivo. Parágrafo único. A defesa coletiva será exercida quando se tratar de: I - interesses ou direitos difusos, assim entendidos, para efeitos deste código, os transindividuais, de natureza indivisível, de que sejam titulares pessoas indeterminadas e ligadas por circunstâncias de fato. ${ }^{20}$

A Constituição Federal já estabeleceu, no artigo 225, que todos têm direito ao meio ambiente ecologicamente equilibrado, reconhecendo o direito ao meio ambiente como direito fundamental. Diante desta constatação, cabe reconhecer que o direito ao meio ambiente tem natureza transindividual, direito difuso, de natureza indivisível, cuja titularidade abrange pessoas indeterminadas e ligadas entre si por circunstâncias de fato. Destarte, sua proteção requer uma tutela processual diferenciada, coletiva, cujo exercício atribui-se a sujeitos com representatividade metaindividual.

\section{Pantanal Mato-grossense: um patrimônio nacional desprotegido}

\subsection{Algumas mudanças legislativas sobre a proteção ambiental no Brasil}

A proteção ambiental no Brasil ganhou relevância jurídica muito recentemente e atualmente é entendida como um valor constitucional, conforme já citado. Mas para que hoje o presente trabalho possa perceber o direito ao meio ambiente como direito fundamental é preciso reconhecer que o caminhar jurídico para o alcance de tal status foi longo.

Antes da independência do Brasil, o ordenamento jurídico vigente no país era o português: as Ordenações Afonsinas e Manuelinas. A legislação portuguesa já fazia menção à proteção ambiental:

19 Neste sentido cabe citar as doutrinas que consideram como sinônimos a expressão direito e interesses: TESHEINER, José Maria Rosa. Ações coletivas pró-consumidor. Revista Ajuris, Porto Alegre, Ajuris, v. 19, n. 54, p. 75-106, mar. 1992. WATANABE, Kazuo. Código Brasileiro de Defesa do Consumidor comentado pelos autores do anteprojeto. 7. ed. Rio de Janeiro: Forense Universitária, 2001. p. 739. FERREIRA, Rony. Coisa julgada nas ações coletivas. Porto Alegre: Sérgio Antônio Fabris, 2004. p. 56. Sobre o tema: MANCUSO, Rodolfo de Camargo. Interesses difusos: conceito e legitimação para agir. 6. ed. São Paulo: RT, 2004. p. 19. SOUZA, Motauri Ciocchtti de. Ação civil pública: competência e efeitos da coisa julgada. São Paulo: Malheiros, 2003. p. 23.

20 BRASIL. Lei $n^{\circ}$ 8.090, de 11 de setembro de 1990. Planalto. Dispõe sobre a proteção do consumidor e dá outras providências. Disponível em: < http://www.planalto.gov.br/ccivil 03/Leis/18078.htm > Acesso em: 15 dez. 2015. 
A legislação portuguesa já protegia o equilibrio ecológico, ainda que concomitantemente procurasse proteger a Coroa. As Ordenações Afonsinas, no Livro V, Título LVIII, proibiam o corte deliberado de árvores frutíferas; o Livro V, Título LXXXIII, das Ordenações Manuelinas vedava a caça de perdizes, lebres e coelhos com redes, fios, bois ou outros meios e instrumentos capazes de causar dor e sofrimento na morte desses animais. ${ }^{21}$

Sob a dominação da Espanha e comando do Rei Felipe II, no Brasil, em 1580, vigeu as Ordenações Filipinas que também mencionavam a preocupação com o meio ambiente: "Livro V, Título LXXXVIII, $\S 7^{\circ}$ : [...] a proibição de qualquer pessoa jogar material que chegasse a matar os peixes e sua criação, ou sujar as águas dos rios e lagos". ${ }^{22}$

Mesmo com a Proclamação da Independência do Brasil em 1822, o país somente em 1824 teve sua primeira Constituição, sem muitas novidades no cenário ambiental. A matéria ambiental foi citada nos artigos 178 e 257, do Código Penal de 1830, que previa a punição pelo corte ilegal de madeiras.

Já no século XX, o Código Civil de 1916, ao tratar do direito de vizinhança pautado no sossego, saúde e segurança, nos artigos 554 a 591, reflexamente, abarcava o direito ao meio ambiente; o Código Civil de 2002 trata do direito de vizinhança e da função social da propriedade.

A Constituição de 1934 fixou as competências entre os entes federados para a proteção do meio ambiente:

Art. 10 - Compete concorrentemente à União e aos Estados: III - proteger as belezas naturais e os monumentos de valor histórico ou artístico, podendo impedir a evasão de obras de arte; Art. $5^{\circ}$ - Compete privativamente à União: XIX - legislar sobre: j) bens do domínio federal, riquezas do subsolo, mineração, metalurgia, águas, energia hidrelétrica, florestas, caça e pesca e a sua exploração; Art. 148 - Cabe à União, aos Estados e aos Municípios favorecer e animar o desenvolvimento das ciências, das artes, das letras e da cultura em geral, proteger os objetos de interesse histórico e o patrimônio artístico do País, bem como prestar assistência ao trabalhador intelectual. ${ }^{23}$

21 FREITAS, Wladimir Passos de. A Constituição federal e a efetividade das normas ambientais. São Paulo: RT, 2000. p. 19.

22 LEMOS, Patricia Faga Iglecias. Direito ambiental: responsabilidade civil e proteção ao meio ambiente. 3. ed. rev., atual. e ampl. São Paulo: RT, 2010, p. 43.

23 BRASIL. Constituição da República dos Estados Unidos do Brasil de 1934. Planalto. Disponível em: < http:// www.planalto.gov.br/ccivil_03/Constituicao/Constituicao34.htm > Acesso em: 2 jan. 2016. 
Nessa mesma época surgiram diplomas legais com grande conteúdo voltado à proteção ambiental, dentre os quais: o Decreto 24.645/1934, que proibia os maus-tratos a animais, o Decreto-lei 23.793/1934 (Código Florestal, que depois foi substituído pela Lei 4.771/1965 e atualmente a Lei 12.651/2012), o Decreto 24.114/1934 (o Regulamento de Defesa Sanitária Vegetal), o Decreto 24.634/1934 (Código das Águas).

A Constituição de 1937 também fez menção à tutela ambiental:

Art. 16 - Compete privativamente à União o poder de legislar sobre as seguintes matérias: XIV - os bens do domínio federal, minas, metalurgia, energia hidráulica, águas, florestas, caça e pesca e sua exploração; Art. 18 - Independentemente de autorização, os Estados podem legislar, no caso de haver lei federal sobre a matéria, para suprir-lhes as deficiências ou atender às peculiaridades locais, desde que não dispensem ou diminuam as exigências da lei federal, ou, em não havendo lei federal e até que esta regule, sobre os seguintes assuntos: a) riquezas do subsolo, mineração, metalurgia, águas, energia hidrelétrica, florestas, caça e pesca e sua exploração; e) medidas de polícia para proteção das plantas e dos rebanhos contra as moléstias ou agentes nocivos. ${ }^{24}$

No mesmo ano foi editado o Decreto-lei nº 25/1937 (organizava o patrimônio artístico e cultural). Em seguida, foi promulgada a Constituição dos Estados Unidos do Brasil de 1946, sem grandes inovações em matéria ambiental e, ainda em sua vigência, nasceu a Lei 4.594/1964 (o Estatuto da Terra), que trata do interesse agrário, de certa forma indissociável do direito ao meio ambiente, depois, em 18/09/1965, foi promulgado o Código Florestal.

A Constituição de 1967 acompanhou a sua antecessora no que diz respeito à matéria ambiental. Também na década de 60 outros textos legais fizeram referência ao meio ambiente, como a Lei de proteção à fauna, de 03/01/1967 (Lei 5.197/67); o Decreto-lei 221, de 28/02/1967 (Código de Pesca); a Lei da Política Nacional de Saneamento (Lei 5.318/67).

Na vigência da Emenda Constitucional de 1969, em plena ditadura militar, independentemente de críticas ou aplausos a essa época que faz parte da história do nosso país, certo é que durante esse lapso temporal vários textos legislativos de repercussão atual foram promulgados, como

24 BRASIL. Constituição da República dos Estados Unidos do Brasil de 1937. Planalto. Disponível em: < http:// www.planalto.gov.br/ccivil_03/Constituicao/Constituica037.htm > Acesso em: 2 jan. 2016. 
a Lei da Ação Civil Pública (Lei 7.347/1985) e a Lei da Política Nacional do Meio Ambiente (Lei 6.938/1981). A primeira compõe o microssistema processual coletivo brasileiro, que trata da tutela processual de interesses/ direitos transindividuais, na modalidade direito difuso, pois o meio ambiente é um direito difuso; e a segunda traz o conceito atual de meio ambiente, como já analisado.

E, por fim, foi promulgada a Constituição Federal de 1988, uma constituição ambiental, que trata do meio ambiente em um capítulo exclusivo, bem como em diversos dispositivos espalhados pelo corpo constitucional. Conforme Leciona Barroso, "as normas de tutela ambiental são encontradas difusamente ao longo do texto constitucional". ${ }^{25}$

O capítulo constitucional que faz referência à proteção ambiental é um avanço constitucional em termos de preservação dos recursos naturais. Assim, aduz Canotilho que:

Ao abraçar esta concepção holística e juridicamente autônoma do meio ambiente, o constituinte de 1988 distancia-se de modelos anteriores, praticamente fazendo meia-volta, especialmente ao admitir que: o meio ambiente dispõe de todos os atributos requeridos para o reconhecimento jurídico expresso, no patamar constitucional; tal reconhecimento e amparo se dá por meio de uma percepção ampliada e holística, isto é, parte-se do todo (a biosfera) para se chegar aos elementos; o todo e os seus elementos são apreciados e juridicamente valorizados em uma perspectiva relacional ou sistêmica, que vai além da apreensão atomizada e da realidade material individual desses mesmos elementos (ar, água, solo, florestas, etc...). ${ }^{26}$

Diante de toda esta construção histórica constitucional-infralegal, pergunta-se: e o Pantanal Mato-grossense, santuário ecológico, está protegido pela Constituição Federal? Existe uma lei federal em vigência que garanta a sua preservação? Ou será que este bioma está desprotegido juridicamente? É justamente sobre estes questionamentos que versará o próximo tópico.

25 BARROSO, Luis Roberto. A proteção do meio ambiente na Constituição brasileira. Revista Forense, v. 317, p. $177,1992$.

26 CANOTILHO, Joaquim Gomes; LEITE, José Rubens Morato. Direito constitucional ambiental brasileiro. São Paulo: Saraiva, 2007. p. 84-85. 


\subsection{A "proteção jurídica" do Pantanal Mato-grossense como patrimônio nacional}

O Pantanal é uma das maiores áreas úmidas do planeta. A sua extensão é muito controvertida entre os estudiosos do tema, como aduzem Cátia Nunes da Cunha, Maria Teresa e Wolfgang:

Hamilton et al. (1996) indicam uma área total de $137.000 \mathrm{~km}^{2}$ baseando-se em critérios morfológicos e hidrológicos. Padovani (2010), usando o nível de inundação máxima como limite e incluindo manchas sedimentares internos não inundados estima uma área total de $150.500 \mathrm{~km}^{2}$. Cerca de $130.000 \mathrm{~km}^{2}$ pertencente aos estados brasileiros de Mato Grosso e Mato Grosso do Sul, $15.000 \mathrm{~km}^{2}$ à Bolívia e $5.000 \mathrm{~km}^{2}$ ao Paraguai. A área periodicamente inundada varia de acordo com o nível médio máximo dos períodos estudados. ${ }^{27}$

O Pantanal, uma das maiores planícies de sedimentação do mundo, ocupa grande parte do centro-oeste brasileiro e se estende pela Argentina, Bolívia e Paraguai, onde recebe outras denominações. Dificilmente pode ser estabelecido um cálculo exato de suas dimensões, sabendo-se, porém, que a porção brasileira, localizada em partes dos estados de Mato Grosso e de Mato Grosso do Sul, está estimada em cerca de $150.000 \mathrm{~km}^{2}$ :

A sua área aproximada é de $150.355 \mathrm{~km}^{2}$, segundo dados do IBGE de 2004, ocupando assim 1,76\% da área total do território brasileiro. Em seu espaço territorial o bioma, que é uma planície aluvial, é influenciado por rios que drenam a bacia do Alto Paraguai..$^{28}$

O Pantanal é uma área úmida sujeita a um pulso de inundação normalmente bem conhecido, composto por uma fase aquática e outra terrestre. Este pulso de inundação é que permite a exuberância deste ecossistema, a variabilidade anual alternada entre enchentes e secas; chuva e estiagem, respectivamente, representam o fator ecológico fundamental para o equilibrio deste meio ambiente: Na paisagem pantaneira, a fisionomia altera-se profundamente nas duas estações bem definidas do ano: a seca e a chuvosa. Durante a seca, nos campos extensos cobertos predominantemente por gramíneas e vegetação de cerrado, a água de superfície chega a escassear, restringindo-se aos rios perenes, com leito definido, às grandes lagoas próximas a esses rios e a algumas lagoas menores e banhados em áreas mais baixas

27 CUNHA, Cátia Nunes da; PIEDADE, Maria Tereza Fernandes; JUNK, Wolfgang J. Classificação e delineamentos das áreas úmidas brasileiras e de seus macrohabitats. Cuiabá: Ed UFMT, 2014. p. 79.

28 PANTANAL. Disponível em: < http://www.mma.gov.br/biomas/pantanal $\geq$ Acesso em: 10 fev. 2016. 
da planície. As primeiras chuvas da estação caem sobre um solo seco e poroso e são facilmente absorvidas. ${ }^{29}$

O Pantanal Mato-grossense, por possuir características diferenciadas, é um santuário ecológico reconhecido nacional e internacionalmente, que merece proteção jurídica.

Dentre os documentos internacionais relacionados à proteção do Pantanal destaca-se a Convenção de Ramsar ${ }^{30}$, que foi celebrada em 1971, na cidade iraniana de Ramsar, em vigor desde 21 de dezembro de 1975, normatiza a

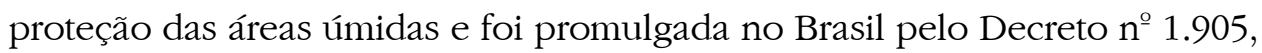
de 16 de maio de 1996.

O artigo $1^{\circ}$, da Convenção, conceitua as áreas úmidas:

Artigo 1 - Para efeitos desta Convenção, as zonas úmidas são áreas de pântano, charco, turfa ou água, natural ou artificial, permanente ou temporária, com água estagnada ou corrente, doce, salobra ou salgada, incluindo áreas de água marítima com menos de seis metros de profundidade na maré baixa. ${ }^{31}$

Apesar das dificuldades em se definir o que sejam estas áreas úmidas, não há dúvidas da importância de sua preservação. A Convenção prevê que o Brasil, enquanto signatário, deve formar o seu Sítio Ramsar, indicando áreas úmidas de importância internacional. Dentre as áreas úmidas que o Brasil já indicou para comporem a Lista de Sítios Ramsar, três se encontram no Pantanal, sendo duas em Mato Grosso e uma em Mato Grosso do Sul: Reserva particular de patrimônio natural Sesc Pantanal (MT), Reserva particular de patrimônio natural - Fazenda Rio Negro (MS) e Parque Nacional do Pantanal Mato-Grossense (MT). ${ }^{32}$

Por determinação desta Convenção, em 2003 foi criado o Comitê Nacional de Zonas Úmidas (CNZU) ${ }^{33}$, com o objetivo de criar um Plano Nacional de Zonas Úmidas, mas este plano até hoje não atende aos objetivos da Convenção. As Recomendações no 02/2010 e 06/2012, do Comitê Nacional de Zonas Úmidas (CNZU) visam à elaboração de uma lei que efetivamente proteja o Pantanal.

29 Dados gerais do Pantanal. Portal pantanal o guia do santuário ecológico. Disponível em: $<\underline{\text { http: } / / \text { www. }}$ portalpantanal.com.br/dadosgerais.html $\geq$ Acesso em: 5 fev. 2016.

30 BRASIL. Dispõe sobre o Decreto 1.905, de 16 de maio de 1996. Planalto. Disponível em: < http://www.planalto. gov.br/ccivil 03/decreto/1996/D1905.htm $\geq$ Acesso em: 8 dez. 2016.

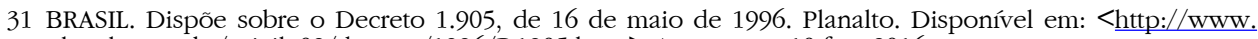
planalto.gov.br/ccivil_03/decreto/1996/D1905.htm > Acesso em: 10 fev. 2016.

32 SERAFINI, L. Z. Proteção jurídica das áreas úmidas e os direitos Socioambientais. 2007. Dissertação (Mestrado)- Programa de Pós-Graduação em Direito da PUC-PR, Curitiba, 2007. Disponível em: <http://www. dominiopublico.gov.br/download/teste/arqs/cp024867.pdf > Acesso em: 15 jan. 2016.

33 MINISTÉRIO DO MEIO AMBIENTE. Convenção de Ramsar. Disponível em: < http://www.mma.gov.br/ biodiversidade/biodiversidade-aquatica/zonas-umidas-convencao-de-ramsar > Acesso em: 17 jun. 2016. 
Mais especificamente, a recomendação CNZU n ${ }^{\circ} 6^{34}$, de 2012, recomenda à Casa Civil da Presidência da República do Brasil que seja criado um grupo de trabalho interministerial com a finalidade de propor a Lei do Pantanal; também recomendou à Agência Nacional de Águas (ANA) que elaborasse o Plano Estratégico de Recursos Hídricos da Região Hidrográfica do Paraguai, levando em conta a vazão ambiental (ou hidrograma ecológico) nos rios já barrados, de modo a compatibilizar a geração de energia e demais usos com a conservação da biodiversidade, a garantia das necessidades de água do ecossistema e a manutenção do equilibrio hidro-ecológico do bioma Pantanal, em articulação com a elaboração do Macrozoneamento Econômico da região, salientando que deverão ser promovidas as condições necessárias à criação e funcionamento do respectivo Comitê de Bacia. Por sua vez, a Recomendação CNZU nº 06/2012 preocupa-se com a expansão de projetos de geração de energia hidrelétrica em prejuízo à conservação do pulso de inundação do Pantanal Mato-grossense.

No ano de 2000, o Pantanal Mato-grossense recebeu dois títulos da Organização das Nações Unidas para a Educação, Ciência e Cultura (Unesco): o de Reserva da Biosfera e o de Patrimônio Natural da Humanidade.

As Reservas da Biosfera ${ }^{35}$ formam uma rede mundial de áreas voltadas à conservação do patrimônio natural e cultural com a implementação do desenvolvimento sustentável. O título concedido pela Unesco ao Pantanal Mato-grossense como Reserva da Biosfera reconhece ao bioma relevância internacional.

O título de Patrimônio Natural da Humanidade ${ }^{36}$ foi dado ao complexo de áreas protegidas do Pantanal pela Unesco também em 2000. Este título se deve ao fato de que este bioma precisa ser protegido por organismos nacionais e internacionais devido à exuberância natural que possui.

Diante de tal importância ecológica, se justifica a preservação do Pantanal Mato-grossense em documentos internacionais.

No cenário jurídico nacional, a Constituição Federal de 1988, que reconhece o meio ambiente como direito fundamental, no capítulo referente ao meio ambiente, mais precisamente no artigo $225, \S 4^{\circ}$, reconhece o Pantanal Mato-grossense como patrimônio nacional:

\footnotetext{
34 EMBRAPA. As Recomendações do Comitê Nacional de Zonas Úmidas. Disponível em: < http://www.cpap. embrapa.br/pesca/online/PESCA2012_CNZU1.pdf > Acesso em: 23 ago. 2016.

35 MAB/UNESCO. O Programa MAB (Man and the Biosphere) e as Reservas da Biosfera. Disponivel em: < http://www.rbma.org.br/mab/unesco_01_oprograma.asp > Acesso em: 22 jul. 2016.

36 UNESCO. Representação da UNESCO no Brasil. Disponível em: < http://www.unesco.org/new/pt/brasilia/ culture/world-heritage/list-of-world-heritage-in-brazil/pantanal-conservation-area/\#c1467473 > Acesso em: 2 jul. 2016.
} 
Art. 225. [...] § $4^{\circ}$ A Floresta Amazônica brasileira, a Mata Atlântica, a Serra do Mar, o Pantanal Mato-Grossense e a Zona Costeira são patrimônio nacional, e sua utilização far-se-á, na forma da lei, dentro de condições que assegurem a preservação do meio ambiente, inclusive quanto ao uso dos recursos naturais.

Cabe ressaltar que a Constituição dos Estados Unidos do Brasil de $1937^{37}$ já reconhecia os bens ambientais como patrimônios nacionais e a atual Constituição atribuiu ao Pantanal Mato-grossense o status de patrimônio nacional. Mas, efetivamente, qual o significado deste reconhecimento?

A doutrina ambiental constitucional não faz numerosos comentários sobre o tema, mas reconhece o termo patrimônio nacional como uma riqueza ecológica brasileira que precisa de cuidados especiais, de proteção mais efetiva. Neste sentido Milaré:

A expressão patrimônio nacional, que se refere o dispositivo, não tem, à evidência, o sentido de propriedade federal ou do Estado, mas de riqueza que, neste País, herdamos com a obrigação de preservar e transmitir às gerações futuras, sem perda, é claro, de seu adequado aproveitamento econômico. Deveras, qualificado o meio ambiente como um bem pertencente à coletividade - bem de uso comum do povo - não integra o patrimônio disponível do Estado. ${ }^{38}$

José Afonso da Silva entende que a integração ao patrimônio nacional não implica transferência do domínio sobre as áreas citadas (a Floresta Amazônica brasileira, a Mata Atlântica, a Serra do Mar, o Pantanal Mato-Grossense e a Zona Costeira) para a União:

[...] na verdade, o significado primeiro e político da declaração constitucional de que aqueles ecossistemas florestais constituem patrimônio nacional está em que não se admite qualquer forma de internacionalização da Amazônia ou de qualquer outra área. ${ }^{39}$

Segundo Cecilia Franco, o conceito de patrimônio nacional é no sentido de que:

37 O artigo 134, caput, da Constituição dos Estados Unidos do Brasil de 1937, já reconhecia os bens ambientais como patrimônios nacionais ao prelecionar que os atentados contra os monumentos históricos, artísticos e naturais, assim como as paisagens ou os locais particularmente dotados pela natureza serão equiparados aos atentados cometidos contra o patrimônio nacional. BRASIL. Constituição da República dos Estados Unidos do Brasil de 1937. Planalto. Disponível em: < http:// www.planalto.gov.br/ccivil 03/Constituicao/Constituicao37. $\underline{\mathrm{htm}}>$ Acesso em: 20 out. 2016.

38 MILARÉ, E. Direito do ambiente: Doutrina - prática - jurisprudência - glossário. São Paulo: RT, 2012. p. 83.

39 SILVA, José Afonso da. Comentário contextual à constituição. 2. ed. de acordo com a Emenda Constitucional 52 de 8.3.2006 (DOU 9.3.2006). São Paulo: Malheiros, 2006. p. 843. 
O patrimônio nacional constitui o conjunto de bens materiais e imateriais que despertam alguma espécie de interesse para a nação, com ela mantendo um vínculo intrínseco que se liga à sua própria personalidade, definindo-a e projetando-a enquanto Estado e individualizando e identificando-a enquanto povo, não se admitindo qualquer forma de internacionalização de tais bens. ${ }^{40}$

A jurisprudência reconhece que o Pantanal, enquanto patrimônio nacional, merece uma proteção jurídica diferenciada, especial:

EMENTA - Ação direta baseada nos artigos $225,4^{\circ}$ e $5^{\circ}$, XII, da Constituição. Sem negar a relevância da fundamentação mas ponderado o interesse coletivo na preservação do meio ambiente, infere-se por maioria, a cautelar, quanto ao artigo $1^{\circ}$ do Decreto $n^{\circ} .99 .547-90$, que proibe, por prazo indeterminado, o corte e a respectiva exploração da vegetação nativa da Mata Atlântica. Cautelar indeferida, por unanimidade, quanto ao art. $2^{\circ}$, do mesmo Decreto, que dispõe sobre o exercício da fiscalização de projetos pelo IBAMA. (...) O que vejo é que, depois de afirmar no artigo 225 que o meio ambiente ecologicamente equilibrado é bem de uso comum do povo, no $\S 4^{\circ}$, o artigo 225 estabelece duas normas: a primeira, que a Floresta Amazônica, a Mata Atlântica e os demais setores territoriais, ali mencionados, são patrimônios nacionais. A dificuldade de identificação do alcance dessa declaração de que a Mata Atlântica constitui patrimônio nacional, a meu ver, com todas as vênias, não permite, malgrado a autoridade do Professor Reale, que se diga apenas que a Constituição o disse em sentido retórico ou figurado. Isso tem de ter um sentido jurídico. E, a meu ver, pelo menos não é de descartar, à primeira vista, o que nesse debate já se aventou: que o "patrimônio nacional" está aqui no sentido de objeto de uma proteção excepcionalíssima da ordem jurídica. ${ }^{41}$

A Magna Carta, no artigo 225, $\S 4^{\circ}$, ressalta que deve ser criada uma lei específica para a proteção do patrimônio nacional Pantanal Mato-grossense. José Afonso da Silva sustenta que em matéria ambiental "a competência legis-

40 NASCIMENTO, Cecilia Franco Sisternas Fiorenzo do. O mercado interno como patrimônio nacional. São Paulo, 2007. p. 104. Disponível em: $<$ http://up.mackenzie.br/stricto-sensu/direito-politico-e-economico/teses-e-dissertacoes-detalhada/artigo/o-mercado-interno-como-patrimonio-nacional/> Acesso em: 21 out. 2016.

41 BRASIL. Supremo Tribunal Federal. ADI MC 487-5/ DF. Relator: GALLOTTI, Octavio. Publicado no DJ de 11-04-1997. Disponível em: < http://redir.stf.jus.br/paginadorpub/paginador.jsp?docTP=AC\&docID=346416> Acesso em: 10 jan. 2016. 
lativa é atribuição que o Poder Legislativo tem para legislar a respeito de temas ligados ao meio ambiente". ${ }^{42}$

A competência legislativa para a proteção do meio ambiente Pantanal é concorrente, isto é, compete à União, ao Estado e ao Distrito Federal a elaboração de leis que o protejam, obedecendo à disposição constitucional.

A Constituição brasileira reconhece a necessidade de proteção jurídica para o Pantanal que se encontra situado em dois estados brasileiros (Mato Grosso e Mato Grosso do Sul), mas não existe uma lei federal especifica para tutelar este ecossistema.

Ainda com base na competência legislativa concorrente, o artigo $24, \S 3^{\circ}$, da Constituição Federal, enfatiza que não existindo lei federal que tutele o meio ambiente, os estados podem exercer sua competência legislativa plena.

Obedecendo aos preceitos constitucionais, é que foi promulgada a Lei Estadual $n^{\circ}$ 8.830/2008. Este diploma vem para suprir a necessidade de legislação federal especifica para proteção do bioma que alcançou a categoria de patrimônio nacional. No estado de Mato Grosso desde 2008 está em vigência a Lei Estadual no 8.830/2008, que, além de dar outras providências, dispõe sobre a Política Estadual de Gestão e Proteção à Bacia do Alto Paraguai no âmbito do estado de Mato Grosso.

Por óbvio, esta lei tem vigência no estado de Mato Grosso, protegendo a área pantaneira localizada neste estado, isto é, cerca de 35\% deste bioma, não produzindo efeito legal em $65 \%$ do Pantanal que está situado no estado de Mato Grosso do Sul.

A citada lei é formada por dispositivos conceituais e principiológicos que ao menos textualmente se harmonizam com os preceitos constitucionais, mas a delimitação da aplicação da lei abrange apenas a planície alagável da Bacia do Alto Paraguai, excluindo o entorno do Pantanal, resultando numa proteção deficiente deste bioma, cuja riqueza natural decorre sobretudo da umbilical relação entre os planaltos circundantes e a planície alagável.

Assim aduz Carlos Teodoro Irigaray:

No que diz respeito à gestão propriamente dita das "áreas de entorno" da área alagável, nenhum avanço pode ser apontado, o que é lamentável, pois a grande maioria dos problemas que afetam o pantanal ocorre em seu entorno, onde estão instaladas extensas lavouras de grão, em solo frágil, onde são depositadas grande quantidade de fertilizantes e pesticidas que acabam carreados, juntamente com os bancos de areia

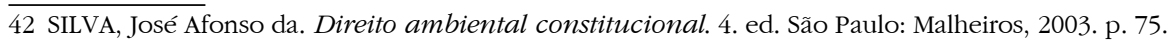


que estão aterrando aos poucos a bacia pantaneira. (...) A lei estadual supre uma omissão relevante e abre perspectivas para uma gestão integrada e capilarizada do Pantanal, contudo, esse bioma, que constitui verdadeiro santuário ecológico reclama a ausência de legislação federal específica que possa dar maior efetividade e aplicabilidade ao reconhecimento constitucional do Pantanal Mato-Grossense como "patrimônio nacional". ${ }^{43}$

Como não existe legislação federal específica regulamentando a utilização dos recurso naturais do Pantanal, algumas leis federais, naquilo que forem compatíveis, serão aplicadas para tutelar este bioma, como a Lei 12.651/2012, principalmente no que diz respeito às áreas de preservação permanente.

O artigo 2ํㅡㄹ alínea “a”, do Antigo Código Florestal - Lei Federal nº 4.771/65, previa a definição de área de preservação permanente, nos seguintes termos: Art. $2^{\circ}$ Consideram-se de preservação permanente, pelo só efeito desta Lei, as florestas e demais formas de vegetação natural situadas: [...] a) ao longo dos rios ou de qualquer curso d'água desde o seu nível mais alto em faixa marginal cuja largura mínima será. ${ }^{44}$

Mesmo existindo posicionamentos diversos sobre a interpretação do artigo $2^{\circ}$, alínea "a", do Velho Código Florestal e do artigo $7^{\circ}, \S 1^{\circ}$, da Lei Estadual $n^{\circ}$ 8.830/2008, era possível compreender-se que toda a planície alagável da Bacia do Alto Paraguai constituía-se numa grande e única APP, eis que o critério para a definição destas áreas partia justamente do nível mais alto dos rios, que, no caso do Pantanal, se espraiam e alagam toda a região na época das cheias.

A Lei Estadual n 8.830/2008, sobre a definição de área de preservação permanente, estipulou que:

Art. $7^{0}$. São consideradas áreas de preservação permanente na Planície Alagável da Bacia do Alto Paraguai de Mato Grosso, sem prejuízo da proteção assegurada na legislação federal e estadual: [...] $\S 1^{\circ}$ As faixas marginais de preservação permanente terão como referencial o nível mais alto dos rios e demais cursos d'água, conforme estabelecidos na legislação estadual. ${ }^{45}$

\footnotetext{
43 IRIGARAY, C. T. H. J.; SOUZA, S. C. Os marcos regulatórios no Brasil: uma abordagem histórica crítica - a proteção jurídica do pantanal de Mato Grosso. In: GALBIATI, Carla; SANTOS, José Eduardo (Orgs.). Gestão e educação ambiental: água, biodiversidade e cultura. v. 1. São Carlos: Rima Editora, 2008. p. 15.

44 BRASIL. Lei 4.771, de 15 de setembro de 1965. Revogada - Instituía o Código Florestal. Disponível em: < http://www.planalto.gov.br/ccivil_03/leis/L4771.htm > Acesso em: 13 set. 2016.

45 ESTADO DE MATO GROSSO. Brasil. Lei Estadual nº 8.830, de 21 de janeiro de 2008. Assembleia Legislativa
} 
O Novo Código Florestal foi sancionado em 25 de maio de 2012, revogando a Lei 4.771/65 e suspendendo o disposto no artigo $7^{\circ}$, $\S 1^{\circ}$, da Lei Estadual $n^{\circ}$ 8.830/2008. De acordo com a Lei Federal ํำ12.651/2012 as áreas de preservação permanente ficam assim definidas:

Art. $4^{\circ}$ Considera-se Área de Preservação Permanente, em zonas rurais ou urbanas, para os efeitos desta Lei: I - as faixas marginais de qualquer curso d'água natural perene e intermitente, excluídos os efêmeros, desde a borda da calha do leito regular, em largura mínima de. ${ }^{46}$

Assim, as áreas de preservação permanente serão contadas a partir da borda da calha do leito regular dos cursos d'água. O Novo Código Florestal no artigo $3^{\circ}$, inciso XIX, define o leito regular como 'a calha por onde correm regularmente as águas do curso d'água durante o ano".

Portanto, as faixas marginais da planície alagável da Bacia do Alto Paraguai, que não forem consideradas áreas de preservação permanente, podem ser exploradas. Qual seria a exploração possível e ecologicamente viável no Pantanal?

Utilizando o critério definidor de área de preservação permanente do Novo Código Florestal, percebe-se que uma grande parte do Pantanal ficará desprotegida, não haverá equilibrio ecológico, uma vez que as áreas não mais consideradas de preservação permanente têm grande importância para a existência do bioma.

Aliás, sobre o retrocesso, em termos de proteção ambiental, que representou a promulgação deste último diploma legal, isto é, o Novo Código Florestal, Irigaray aduz que:

No ordenamento infraconstitucional, a norma geral que disciplinava, ainda que parcialmente, as áreas úmidas estavam contidas no Código Florestal (com redação dada pela Lei $\mathrm{n}^{\circ} 7.803$ de 18.7.1989) que as considerava áreas de preservação permanente, portanto submetidas a um regime jurídico de interesse público com imposição de preservação integral e permanente da flora, vedada sua supressão. Embora não houvesse, na citada norma, a expressa referência a essas áreas, a mesma

do Estado do Mato Grosso. Dispõe sobre a política estadual de gestão e proteção à Bacia do Alto Paraguai no Estado de Mato Grosso e dá outras providências. Disponível em: < http://www.al.mt.gov.br/storage/ webdisco/leis/lei 4702.pdf > Acesso em: 27 set. 2016.

46 BRASIL. Lei 12.651, de 25 de maio de 2012. Dispõe sobre a proteção da vegetação nativa; altera as Leis nº 6.938, de 31 de agosto de 1981; 9.393, de 19 de dezembro de 1996 e 11.428, de 22 de dezembro de 2006, revoga as Leis no. 4.771, de 15 de setembro de 1965 e 7.754, de 14 de abril de 1989 e a Medida Provisória ${ }^{\circ}$ 2.166-67, de 24 de agosto de 2001; e dá outras providências. Planalto. Disponível em: $<\underline{\text { http://www.planalto. }}$ gov.br/ccivil_03/_ato2011-2014/2012/lei/112651.htm > Acesso em: 15 jun. 2016. 
estabelecia a chamada APP ciliar como a faixa marginal ao longo dos rios ou de qualquer curso d'água desde o seu nível mais alto, o que abrangia grande parte das áreas úmidas existentes no país (aquelas que ocorrem com a inundação periódica causada pelo transbordamento lateral de rios). Ocorre que mesmo essa tímida proteção, frequentemente ignorada, foi suprimida com a redação em vigor do art. $4^{\circ}$, I da Lei $12.651 / 2012$, que define a APP ciliar como a faixa marginal ao longo de qualquer curso d'água desde a borda da calha do leito regular, o que exclui dessa proteção as áreas periodicamente alagáveis. ${ }^{47}$

Além das legislações já citadas, atualmente existe o Projeto de Lei ${ }^{\circ}$ 750/2011 ${ }^{48}$, de autoria do senador Blairo Maggi, que pretende dispor sobre a Política de Gestão e Proteção do Bioma Pantanal e dar outras providências. Este projeto, conhecido como a Lei do Pantanal, ainda está em discussão. O projeto de lei é muito similar à Lei Estadual nº 8.830/2008.

A proposição está dividida em cinco capítulos. O Capítulo I determina as Disposições Gerais e a Seção I deste Capítulo as definições. O art. $1^{\circ}$ do projeto descreve o Bioma Pantanal como um conjunto de vida vegetal e animal, especificado pelo agrupamento de tipos de vegetação e identificável em escala regional, com influência de clima, temperatura, precipitação de chuvas, pela umidade relativa, e solo que se localiza na Bacia do Rio Paraguai. O parágrafo único do art. $1^{\text {ํ}}$ estabelece que as delimitações do Pantanal brasileiro estão definidas em estudos da Empresa Brasileira de Pesquisa Agropecuária (Embrapa) que possui sede em Corumbá, também conhecida por Embrapa/Pantanal. A Seção II do Capítulo I determina os objetivos e princípios da Política de Gestão e Proteção do Bioma Pantanal.

O Capítulo II descreve as áreas protegidas: área de proteção permanente e área de conservação permanente. O Capítulo III impõe as restrições de uso. O Capítulo IV normatiza o licenciamento ambiental na planície alagável do Pantanal. Por fim, o Capítulo V estabelece as disposições transitórias.

Em agosto de 2012, a Comissão de Constituição e Justiça emitiu um parecer $^{49}$ sobre este projeto de lei, de relatoria do senador Eduardo Lopes. Tal

\footnotetext{
47 IRIGARAY, Carlos Teodoro José Hugueney. Áreas úmidas especialmente "des" protegidas no direito brasileiro: o caso do pantanal mato-grossense e os desafios e perspectivas para sua conservação. Revista de Estudos Sociais, n. 34, v. 17, p. 209-210, 2015.

48 BRASIL. Projeto de Lei do Senado no 750 de 2011. Disponível em: < http://www25.senado.leg.br/web/atividade/materias/-/materia/103831 > Acesso em: 20 jan. 2016.

49 SENADO FEDERAL. Projeto de Lei 750/2011. Dispõe sobre a Política de Gestão e Proteção do Bioma Pantanal e dá outras providências. Disponível em: < https://www25.senado.leg.br/web/atividade/materias/-/ materia/103831 > Acesso em: 21 set. 2016.
} 
parecer deu ensejo ao texto substitutivo do projeto de lei original, que está tramitando na Comissão de Constituição e Justiça.

Assim, ressalta-se que não obstante o trâmite deste projeto de lei - embora tenha recebido do Legislador Constituinte Originário o status de patrimônio nacional - o Pantanal ainda carece de uma proteção jurídica especial, pois não existe legislação federal que proteja especificamente todo o Pantanal Mato-grossense, situado entre Mato Grosso e Mato Grosso do Sul.

A legislação estadual em vigor no estado de Mato Grosso (Lei n. 8.830/2008), ao proteger tão só a planície alagável propriamente dita, revela-se ecologicamente ineficaz, possibilitando que sob ares de legalidade este bioma seja paulatinamente destruído a partir dos planaltos que o circundam e dos quais depende o pulso de inundação, tão importante para o equilibrio de toda a região.

No entanto, a despeito deste grave quadro de desproteção, não se pode desconsiderar o preceito constitucional que concede ao Pantanal o status de patrimônio nacional, daí decorrendo o imperativo fundamental de que este bioma seja protegido por um diploma federal capaz de garantir a manutenção de todas as condições necessárias ao equilibrio deste santuário ecológico, o maior complexo de áreas úmidas do planeta.

\section{Conclusão}

O meio ambiente foi inserido no rol dos direitos merecedores de proteção jurídica por uma questão de necessidade causada pela alarmante incompatibilidade entre a manutenção da qualidade de vida e o modelo econômico adotado pelas sociedades. A possibilidade de acontecerem catástrofes ambientais, provenientes da sociedade de massa e da sociedade de risco, bem como a conscientização do esgotamento dos recursos naturais, contribuiu para uma releitura da importância da manutenção de um meio ambiente ecologicamente equilibrado como direito fundamental.

O Pantanal Mato-grossense, por suas peculiaridades, é reconhecido nacional e internacionalmente.

No âmbito do direito pátrio, o Pantanal Mato-grossense é reconhecido pela atual Carta Magna como patrimônio nacional. A definição jurídica do termo patrimônio nacional, prevista no artigo $225, \S 4^{\circ}$, da Constituição Federal de 1988, ficou a cargo da doutrina e da jurisprudência. Estas sustentam que patrimônio nacional é aquele que não pode ser internacionalizado, pois de 
fundamental interesse para toda a nação brasileira, devendo, portanto, gozar de uma proteção jurídica especial.

O status de patrimônio nacional impõe ao Estado-legislador a edição de lei que discipline a correta utilização dos recursos naturais, objetivando a proteção do meio ambiente Pantanal.

O Pantanal Mato-grossense, apesar de fazer parte da categoria de patrimônio nacional, encontra-se desprotegido juridicamente, pois não há uma legislação federal que o tutele enquanto patrimônio nacional, o que seria mais viável, pois a expressão "mato-grossense" se refere ao Pantanal situado nos dois estados da Federação: Mato Grosso e Mato Grosso do Sul. Logo a lei mais indicada para preservar este bioma seria uma lei federal, de competência da União.

O Código Florestal, que na falta de lei federal especifica deveria protegê-lo, deixou-o ainda mais desprotegido ao definir as áreas de preservação permanente a partir da borda da calha do leito regular e não mais do ponto mais alto das enchentes, desguarnecendo as grandes áreas alagadas do Pantanal.

A Lei Estadual $n^{\circ}$ 8.830/2008, vigente no âmbito do estado de Mato Grosso, protege deficitariamente apenas parte deste bioma, a planície alagável da Bacia do Alto Paraguai, deixando de lado a área no entorno.

As Recomendações nº 02/2010 e 06/2012, emitidas pelo Comitê Nacional de Zonas Úmidas da Convenção de Ramsar, da qual o Brasil é signatário, visam à elaboração de uma lei que efetivamente proteja o Pantanal, mesmo estando em vigor a Lei Estadual nº 8.830/2008.

O Projeto de Lei $n^{\circ} 750 / 2011$, de autoria do senador Blairo Maggi, que dispõe sobre a Política de Gestão e Proteção do Bioma Pantanal e dá outras providências, precisa de muitas adequações para efetivamente proteger este santuário ecológico, tendo em vista que seu texto é muito similar ao da Lei $\mathrm{n}^{\circ}$ 8.830/2008.

Não há questionamento quanto à necessidade de preservação do Pantanal Mato-grossense. Não obstante, este bioma segue padecendo graves danos ambientais; a sua riqueza ecológica não está sendo valorizada e não existe uma legislação especifica que realmente o proteja. Defender e preservar o Pantanal é muito além de uma decisão política, é uma forma de dar efetividade a um direito fundamental: o direito ao meio ambiente sadio e ecologicamente equilibrado.

Diante desta realidade é que se fundamenta o presente trabalho com o objetivo de reconhecer a importância do Pantanal Mato-grossense enquanto um patrimônio nacional, mas que carece de proteção efetiva. A solução mais 
acertada, segundo nos parece, é a promulgação/sanção de uma lei especifica para este bioma, que realmente abarque suas necessidades existenciais e que o efetive como patrimônio nacional.

\section{Referências}

BARROSO, Luis Roberto. A proteção do meio ambiente na Constituição brasileira. Revista Forense, v. 317, p. $177,1992$.

BRASIL. Constituição da República de 1988. Planalto. Disponível em: < http://www.planalto.gov. br/ccivil_03/constituicao/constituicaocompilado.htm > Acesso em: 2. jan. 2016.

. Constituição da República dos Estados Unidos do Brasil de 1934. Planalto. Disponível em: < http:// www.planalto.gov.br/ccivil_03/Constituicao/Constituicao34.htm > Acesso em: 2 jan. 2016.

. Constituição da República dos Estados Unidos do Brasil de 1937. Planalto. Disponível em: < http:// www.planalto.gov.br/ccivil_03/Constituicao/Constituicao37.htm > Acesso em: 2 jan. 2016.

. Dispõe sobre o Decreto 1.905, de 16 de maio de 1996. Planalto. Disponível em: < http:// www.planalto.gov.br/ccivil_03/decreto/1996/D1905.htm > Acesso em: 8 dez. 2016.

.Lei 12.651, de 25 de maio de 2012. Dispõe sobre a proteção da vegetação nativa; altera as Leis $\mathrm{n}^{\circ}$. 6.938, de 31 de agosto de 1981; 9.393, de 19 de dezembro de 1996 e 11.428, de 22 de dezembro de 2006, revoga as Leis $n^{\circ}$. 4.771, de 15 de setembro de 1965 e 7.754 , de 14 de abril de 1989 e a Medida

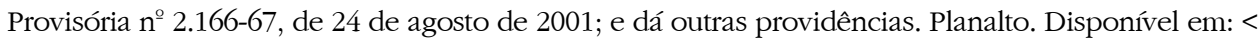
http://www.planalto.gov.br/ccivil_03/_ato2011-2014/2012/lei/112651.htm > Acesso em: 15 ago. 2016.

. Lei 4.771, de 15 de setembro de 1965. Revogada - Instituía o Código Florestal. Disponível em: < http://www.planalto.gov.br/ccivil_03/leis/L4771.htm > Acesso em: 13 set. 2016.

Lei nº 6.938, de 31 de agosto de 1981. Planalto. Dispõe sobre a política nacional do meio ambiente e dá outras providências. Disponível em: < http://www.planalto.gov.br/ccivil_03/Leis/ L6938.htm > Acesso em: 29 dez. 2015.

. Lei $\mathrm{n}^{\circ}$ 8.090, de 11 de setembro de 1990. Planalto. Dispõe sobre a proteção do consumidor e dá outras providências. Disponível em: < http://www.planalto.gov.br/ccivil 03/Leis/18078.

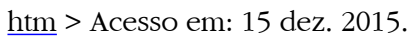

. Projeto de Lei do Senado nº 750 de 2011. Disponível em: < http://www25.senado.leg. br/web/atividade/materias/-/materia/103831 > Acesso em: 20 jan. 2016.

. Supremo Tribunal Federal. ADI MC 487-5/ DF. Relator: GALLOTTI, Octavio. Publicado no DJ de 11-04-1997. Disponível em: < http://redir.stf.jus.br/paginadorpub/paginador. jsp?docTP=AC\&docID=346416> Acesso em: 10 jan. 2016.

BRUNDTLAND, G. H. Nosso Futuro Comum: Comissão mundial sobre meio ambiente e desenvolvimento. 2. ed. Rio de Janeiro: Fundação Getúlio Vargas, 1991.

CANOTILHO, Joaquim Gomes; LEITE, José Rubens Morato. Direito constitucional ambiental brasileiro. São Paulo: Saraiva, 2007.

CUNHA, Cátia Nunes da; PIEDADE, Maria Tereza Fernandes; JUNK, Wolfgang J. Classificação e delineamentos das áreas úmidas brasileiras e de seus macrobabitats. Cuiabá: Ed UFMT, 2014.

DADOS gerais do Pantanal. Portal pantanal o guia do santuário ecológico. Disponível em: < http:// 
www.portalpantanal.com.br/dadosgerais.html > Acesso em: 5. Fev. 2016.

EMBRAPA. As Recomendações do Comitê Nacional de Zonas Úmidas. Disponível em: < http:// www.cpap.embrapa.br/pesca/online/PESCA2012_CNZU1.pdf > Acesso em: 23 ago. 2016.

ESTADO DE MATO GROSSO. Brasil. Lei Estadual n 8.830, de 21 de janeiro de 2008. Assembleia Legislativa do Estado do Mato Grosso. Dispõe sobre a política estadual de gestão e proteção à Bacia

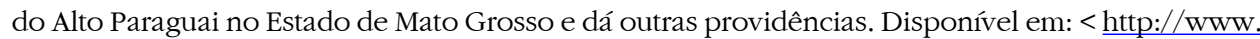
al.mt.gov.br/storage/webdisco/leis/lei_4702.pdf > Acesso em: 27 set. 2016.

FERREIRA, Rony. Coisa julgada nas ações coletivas. Porto Alegre: Sérgio Antônio Fabris, 2004.

FREITAS, Wladimir Passos de. A Constituição federal e a efetividade das normas ambientais. São Paulo: RT, 2000.

GRINOVER, Ada Pellegrini (Coord.). A tutela jurisdicional dos interesses difusos. São Paulo: Editora Max Limonad, 1984.

IRIGARAY, C. T. H. J.; SOUZA, S. C. Os marcos regulatórios no Brasil: uma abordagem histórica crítica - a proteção jurídica do pantanal de Mato Grosso. In: GALBIATI, Carla; SANTOS, José Eduardo (Orgs.). Gestão e educação ambiental: água, biodiversidade e cultura. v. 1. São Carlos: Rima Editora, 2008.

. Áreas úmidas especialmente "des" protegidas no direito brasileiro: o caso do pantanal mato-grossense e os desafios e perspectivas para sua conservação. Revista de Estudos Sociais, n. 34, v. 17, p. 209-210, 2015.

LEMOS, Patricia Faga Iglecias. Direito ambiental: responsabilidade civil e proteção ao meio ambiente. 3. ed. rev., atual. e ampl. São Paulo: RT, 2010.

. Meio ambiente e responsabilidade civil do proprietário: análise do nexo causal. 1. ed. São Paulo: RT, 2008.

MAB/UNESCO. O Programa MAB (Man and the Biosphere) e as Reservas da Biosfera. Disponível em: < http://www.rbma.org.br/mab/unesco 01 oprograma.asp $>$ Acesso em: 22 jul. 2016.

MANCUSO, Rodolfo de Camargo. Interesses difusos. São Paulo: Revista dos Tribunais, 1998.

Interesses difusos: conceito e legitimação para agir. 6. ed. São Paulo: Editora Revista dos Tribunais, 2004.

MILARÉ, E. Direito do ambiente: Doutrina - prática - jurisprudência - glossário. São Paulo: RT, 2012.

MINISTÉRIO DO MEIO AMBIENTE. Convenção de Ramsar. Disponível em: < http://www.mma.gov.br/ biodiversidade/biodiversidade-aquatica/zonas-umidas-convencao-de-ramsar $>$ Acesso em: 17 jun. 2016.

MIRANDA, Jorge. Manual de direito constitucional. 2. ed. t. IV. Coimbra: Coimbra ed., 1993.

NABAIS, José Casalta. O dever fundamental de pagar impostos: contributo para a compreensão constitucional do estado fiscal contemporâneo. Coimbra: Almedina, 1998.

NASCIMENTO, Cecilia Franco Sisternas Fiorenzo do. O mercado interno como patrimônio nacional. São Paulo, 2007. Disponível em: < http://up.mackenzie.br/stricto-sensu/direito-politico-e-economico/teses-e-dissertacoes-detalhada/artigo/o-mercado-interno-como-patrimonio-nacional/ $>$ Acesso em: 21 out. 2016.

ORGANIZAÇÃO DAS NAÇÕES UNIDAS. Declaração da Conferência das Nações Unidas sobre Meio Ambiente. Estocolmo: 5 a 16 de junho de 1972. Disponível em: < http://www.onu.org.br/ rio20/img/2012/01/estocolmo1972 > Acesso em: 10 jan. 2016.

ORGANIZAÇÃO DAS NAÇÕES UNIDAS. Declaração da Conferência das Nações Unidas sobre 
Meio Ambiente e Desenvolvimento. Rio de Janeiro: 3 a 14 de junho de 1992. Disponível em: < http://www.onu.org.br/rio20/img/2012/01/estocolmo1972 > Acesso em: 10 jan. 2016.

PANTANAL. Disponível em: < http://www.mma.gov.br/biomas/pantanal > Acesso em: 10 fev. 2016

PIGNATI, Wanderlei. Avaliação integrada dos impactos dos agrotóxicos na saúde e ambiente em Lucas do Rio Verde no Mato, com ênfase na contaminação do leite materno. Disponível em: < http://www2.camara.leg.br/atividade-legislativa/comissoes/comissoes-permanentes/cmads/ audiencias-publicas/audiencias-publicas/3-07-2012-presenca-de-residuos-de-agrotoxicos-em-leite-materno/heloisa-rey-farza-anvisa/professor-dr.wanderlei-pignati-ufmt $>$ Acesso em: 23. fev. 2016.

RODRIGUES, Marcelo Abelha. Instituições de direito ambiental. v. 1. São Paulo: Max Limond, 2002.

SARLET, Ingo Wolfgang. A eficácia dos direitos fundamentais. 3. ed. rev. atual. ampl. Porto Alegre: Livraria do advogado, 2003.

SERAFINI, L. Z. Proteção jurídica das áreas úmidas e os direitos Socioambientais. 2007. Dissertação (Mestrado)- Programa de Pós-Graduação em Direito da PUC-PR, Curitiba, 2007. Disponível em: $<$ http://www.dominiopublico.gov.br/download/teste/arqs/cp024867.pdf > Acesso em: 15 jan. 2016.

SILVA, José Afonso da. Comentário contextual à constituição. 2. ed. São Paulo: Malheiros, 2006.

. Direito ambiental constitucional. 4. ed. São Paulo: Malheiros, 2003.

SODRÉ, Marcelo. Dignidade Planetária: O Direito e o Consumo Sustentável. In: MIRANDA, Jorge; SILVA, Marco Antonio Marques da (Coord.). Tratado Luso-Brasileiro da Dignidade Humana. São Paulo: Quartier Latin, 2008.

SOUZA, Motauri Ciocchtti de. Ação civil pública: competência e efeitos da coisa julgada. São Paulo: Malheiros, 2003.

TESHEINER, José Maria Rosa. Ações coletivas pró-consumidor. Revista Ajuris, Porto Alegre, v. 19, n. 54, p. 75-106 mar. 1992.

UNESCO. Representação da UNESCO no Brasil. Disponível em: < http://www.unesco.org/new/pt/ brasilia/culture/world-heritage/list-of-world-heritage-in-brazil/pantanal-conservation-area/\#c1467473 > Acesso em: 2 jul. 2016.

WATANABE, Kazuo. Código Brasileiro de Defesa do Consumidor comentado pelos autores do anteprojeto. 7. ed. Rio de Janeiro: Forense Universitária, 2001.

ZAVASCKI, Teori, A. Defesa de direitos coletivos e defesa coletiva de direitos. Revista de informação legislativa, Bras1lia, Senado Federal, v. 32, n. 127, p. 83-96, jul./set. 1995. 